\title{
Jean de Rotrou, Théâtre complet 12, L'Heureux naufrage, Agésilan de Colchos, Clarice
}

\section{Monica Pavesio}

\section{(2) OpenEdition}

1 Journals

\section{Edizione digitale}

URL: http://journals.openedition.org/studifrancesi/10555

DOI: 10.4000/studifrancesi. 10555

ISSN: 2421-5856

\section{Editore}

Rosenberg \& Sellier

\section{Edizione cartacea}

Data di pubblicazione: 1 décembre 2017

Paginazione: 546

ISSN: 0039-2944

\section{Notizia bibliografica digitale}

Monica Pavesio, «Jean de Rotrou, Théâtre complet 12, L'Heureux naufrage, Agésilan de Colchos, Clarice», Studi Francesi [Online], 183 (LXI | III) | 2017, online dal 01 février 2018, consultato il 24 janvier 2021. URL: http://journals.openedition.org/studifrancesi/10555; DOI: https://doi.org/10.4000/studifrancesi. 10555

Questo documento è stato generato automaticamente il 24 janvier 2021.

\section{(c)}

Studi Francesi è distribuita con Licenza Creative Commons Attribuzione - Non commerciale - Non opere derivate 4.0 Internazionale. 


\title{
Jean de Rotrou, Théâtre complet 12, L'Heureux naufrage, Agésilan de Colchos, Clarice
}

\author{
Monica Pavesio
}

\section{NOTIZIA}

JEAN DE ROTROU, Théâtre complet 12, L'Heureux naufrage, Agésilan de Colchos, Clarice, textes établis et présentés par P. Gethner, B. Louvat-Molozay, P. Pasquier, Classiques Garnier, 2016, «Société des Textes Français Modernes», 542 pp.

1 Iniziata nel 1998, sotto la direzione di Georges Forestier, la collezione del Théâtre complet di Rotrou, è giunta al dodicesimo volume. Il tomo contiene tre pièces poco conosciute del drammaturgo francese: le due tragicommedie L'Heureux Naufrage e Agésilas de Colchos e la commedia Clarice, imitata da una commedia italiana del Cinquecento.

2 La prima tragicommedia, risalente probabilmente alla stagione teatrale 1631-32, come afferma P. Gethner nell'introduzione, è una delle pièces di Rotrou più ricche di peripezie. Di fonte sconosciuta, l'opera sarebbe nata dall'unione di temi e procedimenti presenti in alcune tragicommedie precedenti. L'abilità di Rotrou è ormai tale da permettergli di creare qualcosa di nuovo con ingredienti già noti.

3 La seconda pièces, anch'essa una tragicommedia risalente alla stagione 1636-37, presenta, meglio di altre, secondo le parole del curatore P. Pasquier, le grandi doti drammaturgiche di Rotrou, affinate grazie alla sua collaborazione con la Troupe Royale. Imitata da uno dei più famosi romanzi cavallereschi spagnoli, l'Amadis de Gaula, tradotto in francese fin dalla metà del Cinquecento, l'opera presenta un intreccio sorprendente e spettacolare.

4 La terza, adattata da una commedia erudita italiana dell'autore cinquecentesco Sforza Oddi, fu rappresentata intorno al 1641. La curatrice, B Louvat-Molozay, ricostruisce il 
successo della commedia italiana in Francia e studia le modalità di adattamento utilizzate del drammaturgo.

5 Le tre pièces, molto diverse tra loro, sono unite da un denominatore comune: tutte portano in scena effetti spettacolari, scambi di persone, travestimenti, insomma quelle tematiche barocche che fanno di Rotrou, come afferma Jacques Morel nel suo celebre studio del 1968 «le dramaturge de l'ambiguité». 